\title{
Russian Tourism Enterprises' Marketing Innovations to Meet the COVID-19 Challenges
}

\author{
Marina Sheresheva ${ }^{1,2, *(\mathbb{C}) \text {, Marina Efremova }}{ }^{2}$, Lilia Valitova ${ }^{1}$, Anna Polukhina ${ }^{3}$ and Georgy Laptev ${ }^{1}$ (D) \\ 1 Department of Economics, Lomonosov Moscow State University, 119991 Moscow, Russia; \\ lvalit@gmail.com (L.V.); gdlaptev@gmail.com (G.L.) \\ 2 Department of Service and Tourism, National Research Lobachevsky State University of Nizhny Novgorod, \\ 603950 Nizhniy Novgorod, Russia; emvnki@mail.ru \\ 3 Department of Service and Tourism, Volga State University of Technology, 424000 Yoshkar-Ola, Russia; \\ PoluhinaAN@volgatech.net \\ * Correspondence: m.sheresheva@gmail.com
}

Citation: Sheresheva, M.; Efremova, M.; Valitova, L.; Polukhina, A.; Laptev, G. Russian Tourism Enterprises' Marketing Innovations to Meet the COVID-19 Challenges. Sustainability 2021, 13, 3756. https:/ / doi.org/10.3390/su13073756

Academic Editor: Mingaleva Zhanna

Received: 24 February 2021

Accepted: 23 March 2021

Published: 28 March 2021

Publisher's Note: MDPI stays neutral with regard to jurisdictional claims in published maps and institutional affiliations.

Copyright: (c) 2021 by the authors. Licensee MDPI, Basel, Switzerland. This article is an open access article distributed under the terms and conditions of the Creative Commons Attribution (CC BY) license (https:/ / creativecommons.org/licenses/by/ $4.0 /)$.

\begin{abstract}
This paper discusses the results of a study aimed at gaining a deeper understanding of how the COVID-19 pandemic has changed the Russian tourism market and how local tourism enterprises respond to challenges caused by the COVID-19 pandemic. Summarizing their experience of doing business in crisis conditions can allow a more efficient response to similar crises in the future and contribute to a more resilient tourism sector in the aftermath of the pandemic. In order to meet the research objective, we combined various sources of operational statistical information about the state of the industry with the results of a survey conducted in the Nizhny Novgorod region and in-depth interviews with representatives of tourism enterprises. We found that Russian tourism enterprises have proved to be quite resilient by looking for additional opportunities, and paying special attention to staff development and team consolidation. However, there are problems faced by local tourism enterprises in obtaining state support. Therefore, tourism enterprises that rely on themselves and innovate to create services and products adjusted to new customer needs and preferences have a better chance to survive. In particular, the wider use of digital marketing instruments helps SMEs to propose a new value for customers aligned to the new requirements and trends in tourism, such as travel security, prevailing interest in individual and short-term trips for short distances, and the sharply increased demand for domestic tourism destinations.
\end{abstract}

Keywords: tourism; tourism enterprises; SMEs; pandemics; marketing innovations; Russia

\section{Introduction}

The COVID-19 pandemic has already had a significant impact on many sectors of the world economy and on lifestyle and quality of life in contemporary society. Most national governments focused on containing the rate of COVID-19 increase within their countries [1]. Government measures aimed at reducing the rate of COVID-19 spread caused fast and serious damage to almost all industries. All participants of the prior well-established value chains have found themselves in a dramatic situation of "an aggregate supply shock resulting from contagion containment measures with restrained demand and mobility" [2]. Many brands have significantly changed their approach to marketing, and new trends in digital communications have emerged.

The total economic loss in consumer markets due to the COVID-19 pandemic is estimated at around USD 3.8 trillion, or $4.2 \%$ of world GDP [3]. The long-term consequences of the pandemic and the changes in economic actors' behavior have yet to be assessed and comprehended, but it is already obvious today that the implemented quarantine measures and restrictions have led to structural shifts and significant transformations of markets.

As to the tourism and hospitality market that represented approximately one-tenth of global GDP [4], it experienced, in comparison with other industries and sectors, a 
higher degree of the destructive impact caused by COVID-19 and measures to cope with it. Although the World Tourism Organization (UNWTO) predicts a decrease in the number of international tourist arrivals by only $20-30 \%$ in 2020 compared to 2019 , the current situation in world tourism can be described as unprecedented. The closure of borders and the cessation of international flights led to the fact that the global tourism system, in a few months of the pandemic, actually made its way from "overtourism" to "non-tourism" [5].

International, regional, and local travel restrictions immediately affected tourism systems, i.e., international travel, domestic tourism, day visits, and segments as diverse as air transport, cruises, public transport, accommodation, cafés and restaurants, conventions, festivals, meetings, or sports events [5]. Tour sales and accommodation-facility bookings have been stopped, travel has been canceled or postponed, and leisure and entertainment enterprises previously focused on the tourism sector have undergone a significant change in business models due to a greatly reduced flow of customers.

The fall in demand for tourism and hospitality services to a minimum level forced the industry to face serious financial problems [6]. As a result, in the global tourism and hospitality market, 30 to $40 \%$ of enterprises were forced to cease their activities, leaving about 75 million people unemployed [7]. In 2020, the very model of global tourism (already very fragile and unreliable) was facing the threat of final destruction [8].

Thus, it can be argued that the pandemic itself, as well as government measures to combat COVID-19, have already had an unprecedented impact on the global tourism market, modifying both a general "portrait" of the industry and the "rules of the game". In this regard, it is especially interesting to study the current state of the tourism and hospitality sector at all levels, from local to international, and to understand challenges and changes in market actors' behavior.

In particular, the responses of small and medium enterprises (SMEs, enterprises that have up to 250 employees in Russia) to the challenges caused by COVID-19 are of high research interest. It is important to understand SMEs' ways to survive, their assessment of state support measures, and their opinions on opportunities and new niches arising in new conditions of the pandemic and postpandemic world.

The study presented in the paper aims to address the research question regarding how the behavior of Russian tourism SMEs is changing in response to the COVID-19 challenges, and what innovations help them to survive in crisis. In order to understand how tourism SMEs are experiencing a hard situation in tourism caused by the COVID-19 restrictions, we conducted a survey aimed to shed light on the current financial state, government support, and the responding firms' business-strategy adaptation. This will help more deeply comprehend the changes that have taken place and develop strategies for anticrisis mobilization that allow a faster and more efficient response to similar crises in the future. The presented study is neither final nor exhaustive, and aims to raise the discussion of the issue among a wider range of entrepreneurs and academic researchers in order to jointly learn from this global crisis and accelerate the transformation toward sustainable tourism.

The paper is structured as follows. After the introduction, the literature on SMEs behavior during the COVID-19 pandemic and their response on the challenges conditioned by the unexpected circumstances is reviewed. The methodological section describes the context, the data collection process, and analysis. In the next sections, we discuss the situation in the Russian tourism market, and the results of in-depth interviews and survey conducted in the Nizhny Novgorod region. Conclusions and paths for the future research close the paper.

\section{Literature Review}

\subsection{Challenges Businesses Are Facing during the COVID-19 Pandemic}

The challenges for most businesses caused by the COVID-19 pandemic all over the world have received the broad attention of academics and practitioners [9-15]. The resulting economic and social phenomenon from social distancing has led to some swift changes in almost all business landscapes [16] and raised questions of possible bankrupt- 
cies, not only for SMEs, but for many well-known brands in many industries, as consumers stay at home and economies are shut down [17]. There are few authors claiming that "the current pandemic has had enormous-but hopefully short-term-effects on all our lives" [11] (p. 284). Most researchers have the opinion that the COVID-19 pandemic is a society-changing event that could have a profound long-term impact on all aspects of business $[18,19]$.

Many experts claim that the pandemic is more likely to affect small businesses than large ones, and no one denies that the impact on SMEs was huge, in many cases irreversible [20-24]. SMEs, with their limited ability to counterattack the involved risks and afford the costs in times of slowing business activities, are facing a lack of funds and liquidity, employees, customers, and technology [25]. As an example, [26] discuss the evidence from a sample of 4807 SMEs in Sichuan Province, China. They admit that most SMEs were unable to resume work because of a shortage of epidemic-mitigation materials, the inability of employees to return to work, disrupted supply chains, and reduced market demand. Many SMEs were also facing cash-flow risks, as they had to continue to pay for various fixed expenditures even though they had little or no revenue.

At the same time, SMEs have more flexibility when threats or opportunities present themselves in their environment, and thus possess characteristics that could help them survive crises. This statement is based on a literature study on 69 manuscripts that studied SMEs in previous crises [27], therefore one could expect them to exhibit the same characteristics during the COVID-19 pandemic [28,29].

Drawing upon unique data from 456 SMEs in the midst of an unfolding crisis, [30] demonstrates how SMEs acted immediately by deferring investments, reducing labor costs and expenses, and negotiating contracts and terms. Their data also highlight how SMEs in an unfolding crisis are reluctant to commit to any action that will increase their debt-to-equity ratio.

Among the most used anticrisis measures mentioned by the firms surveyed in different countries, along with loans, forced staff reduction or reducing wages, there were changes in business concepts or marketing strategies, as well as the wider use of digital technologies [31-33].

In the context of crisis, it is also highly important for SMEs to cooperate, since combining scarce resources and sharing knowledge within an ecosystem brings organizations more grounds for sustainability $[34,35]$. Network members not only share resources, but commonly learn to face the challenges of critical situations [36].

\subsection{Tourism Firms' Challenges in Pandemic and Postpandemic Environment}

The tourism industry was among the first and most badly hit by the COVID-19 pandemic. Thousands of tours all over the world had to be interrupted, and those planned for later dates had to be canceled or postponed. Social-distancing requirements, restrictions on movement, and closed borders have led to an almost complete disappearance of demand for tourism and hospitality services, and a drop in the incoming flow of payments in April-May 2020 to almost zero. Due to the specifics of tourism and hospitality services' production and consumption, each cancellation led to losses of profit by market actors, and, ultimately, badly damaged their ability to fulfill obligations to tourists and their own staff [5].

The evolution of the COVID-19 pandemic and its economic impact is highly uncertain, which makes it difficult not only for policymakers to formulate an appropriate macroeconomic policy response, but also for industry actors, especially SMEs, to find ground for survival and further development $[37,38]$. Managers are literally "surfing" through this crisis without medium- or long-term strategies, and adapting a business model/strategy in the short run can be the difference between failure and survival.

Nevertheless, "As the world grapples with the realities of the global pandemic there is an opportunity to rethink exactly what tourism will look like for the decades ahead" [39] and to find new opportunities for sustainable tourism [40,41]. 
Some authors express their conviction that contactless technologies, including robots and artificial intelligence (AI), may help tourism and hospitality businesses to decrease their fixed costs, and improve liquidity and resilience [42,43]. Besides, more cooperation, mutual assistance, and closer interaction of all parties interested in tourism recovery and further development will become highly important aspects [7]. For SMEs, with their scarce resources, embeddedness in a broader system of mutually beneficial collaboration between local tourism destination stakeholders can be the issue of survival $[44,45]$.

Finally, there are a number of papers dedicated to the issues of state support for SMEs operating in local tourism destinations [46-48]. The World Tourism Organization (UNWTO) has developed several groups of recommendations for overcoming the COVID19 crisis in the industry, aimed at managing and mitigating its impact, and at providing incentives for the industry to recover and prepare for future postcrisis operations [49]. Each of the developed groups of recommendations contains a detailed list of measures to preserve existing and create new jobs, maintain the liquidity of market participants, provide incentives for investment, strengthen tourism management at all levels, and increase the sustainability of tourism enterprises. However, even when governments not only follow these recommendations, but also develop additional specific measures, the evidence is that SMEs do not always benefit from them. Accordingly, it is necessary to study the availability and feasibility of government measures in terms of their short-term and long-term effectiveness.

\subsection{Shift in Consumer Behavior: What Is Important for Tourism?}

In tourism, there is a huge shift in customer behavior caused or catalyzed by the pandemic. COVID-19 is not only resulting in global crises for the tourism and hospitality sector, but also substantially changing consumers' wants and market demands that were satisfied by traditional value chains and business models [5,38]. As [50] underline, "What was previously taken for granted may not hold anymore in the COVID-19 era", urging both researchers and practitioners to critically reassess the previous "normal".

There is an obvious consensus among industry experts that in the pandemic and postpandemic period, tourism and hospitality actors will experience new challenges in the field of customer relations [51,52]. Tourism and hospitality businesses will have to focus not on retention, but on returning consumers, studying new consumer habits and preferences, and researching the practices of introducing and using new safe service technologies [53]. All actors in the world tourist market should adjust to the significant changes in the geography of international tourist trips and their intensities.

The most important changes are the enormous disease-avoidance motive and fastgrowing interest of tourists in all countries in domestic destinations [54], both "close-tohome" ones for short (i.e., weekend) trips, and new ones for longer trips. Potential tourists, realizing the dangers and consequences of a novel coronavirus (COVID-19) disease, are likely to be guided by travel-safety considerations when planning their travels, and are likely to prefer domestic tourism to outbound tourism [55]. At the same time, tourist regions and destinations in which the number of COVID-19 cases (for both locals and tourists) is high, risk losing their attractiveness in the eyes of travelers and face difficulties in attracting new guests in the future due to image deterioration [56].

Since tourism is a human activity that is closely linked with human behavior in interaction with other people, economies, and environments [57], many papers are underlying the crucial importance of strict adherence to the necessary antipandemic measures introduced by authorities, and to the recommendations of healthcare organizations [58,59]. Securing sustainable tourism-development processes will require social-distancing measures for such tourism types as religious, adventure, farming tourism, and MICE tourism that brings large groups together for a specific purpose like meetings, incentives, conferences, exhibitions. The wide dissemination of medical knowledge concerning COVID-19 among personnel is now an inevitable condition for the tourism and hospitality sector revival that will allow market actors to ensure the required level of service safety while maintaining 
service quality [60]. This implies additional infrastructure investments (e.g., cleaning and sanitizing systems, hard flooring, air handling systems, etc.) to maintain a safe and secure environment for guests and personnel [61].

Social distancing is already the practice of hospitality enterprises during the procedures of arrival and departure of guests, catering, and cultural and educational events. It will surely stay, though maybe not in such an intense manner, in postpandemic times. Moreover, air travel and cruises will have to use personal protective equipment (PPE), and transport companies and individual carriers will need to develop and implement new rules and standards to ensure the safety of tourist transport $[62,63]$.

It is also important to underline that the prepandemic trends of service digitalization and the growing role of electronic word-of-mouth as a powerful communication tool [64] became even more explicit in the new circumstances. In this regard, it becomes critical for tourism businesses to develop differentiation strategies that take into account the role of online customer relationships, and to use the digital-marketing toolkit $[65,66]$.

Therefore, for tourism enterprises that are looking for a chance to survive in pandemic and postpandemic time, marketing innovations are needed that ensure the creation of services adjusted to the new customer fears, needs, and preferences.

\section{Materials and Methods}

In order to meet the objective of the research, a number of methods and techniques are combined, namely desk research, statistical analysis, case study method, and analysis of empirical data obtained by means of small and medium-sized enterprises survey.

To assess the overall conditions in the industry, we considered a number of information sources on the situation in the Russian tourism and hospitality industry. These were the official Rosstat data on statistical reporting forms, sectoral cash-flow monitoring of the Bank of Russia, data on tax-reporting forms from the Federal Tax Service, information from the register of small and medium-sized businesses of the Federal Tax Service and the register of tour operators, and the Sberbank indices of consumer activity. To collect empirical data, we used questionnaires and expert interviews.

The empirical part of the study was conducted in August 2020 in the Nizhny Novgorod region of the Russian Federation. In the first stage, we used an online questionnaire designed in accordance with the logic and objectives of the study, namely: (1) identify the impact of the Covid-19 pandemic on small and medium-sized tourism enterprises; (2) summarize anticrisis solutions that allowed enterprises to survive in an unprecedented crisis in the tourism market, and depict marketing innovations used in their business tactics. The survey questions aimed to obtain the following positions from enterprise data: assessment of the current financial situation; ways to cope with the consequences of the pandemic; peculiarities of interaction with staff, customers, and contractors in pandemic time; prospects for postpandemic business development; and characteristics of the particular business. Altogether, 81 directly e-mailed questionnaires were sent to the websites of enterprises that are members of the Nizhny Novgorod Region Hoteliers Association and the Nizhny Novgorod Tourist League, which received 38 and 43 questionnaires, respectively. The final sample size was 63 tourism and hospitality businesses. The sample is represented by top managers $(49 \%)$, sales managers (38\%), and marketing managers $(13 \%)$.

Additional information was collected by means of in-depth, semistructured interviews with representatives of the largest tourism and hospitality enterprises. The choice of in-depth interviews as a method of obtaining empirical data allowed deeper understanding of the respondents' attitudes to the studied issues by gaining access to insights into their opinions, emotions, and experiences [67]. Key themes to unveil by means of in-depth interviews were as follows: What was the reaction of entrepreneurs on COVID19-any product/service, target customers, customer journey, value proposition? In the response-was there any leverage of previous assets, any redesign of networks, experiences, relationships? Did they use any new technology (or accelerated adoption of existing technology)? Were the changes successful? Does it make sense for the firm to keep changes 
in place in the "post-COVID" era? We obtained company/entrepreneur profiles, as well as key insights and learnings reported by the respondents.

\section{Results}

\subsection{The Impact of the Pandemic on the Russian Tourism Market}

In 2020, the Russian tourism sector faced a sharp collapse of business activity: tourism companies were not able to fulfill their obligations to tourists and their employees, and the sector badly needed state support. In the spring and summer of 2020, federal authorities provided systematic measures to save the industry that resulted in some stabilization [68].

Taking into account the enormous, underutilized potential of domestic and inbound tourism, local destinations, including new ones, are now the focus of Russian government support that aims to settle the conditions for the successful resumption of tourism activities in the long term. This is not that easy, since in the prepandemic period, outbound tourism flows prevailed, there was a weak tourism infrastructure, low professional skills of most entrepreneurs and staff in the sector, and lack of tourism support experience on all levels $[69,70]$. At the same time, there could be new opportunities to boost tourism development in the new challenging conditions, and to exceed prepandemic indicators of local-destination development in Russia [38,71-73].

The statistics we have studied show that social-distancing requirements, restrictions on movement, and closed borders led to an almost complete disappearance of demand for services in the Russian tourism market and a drop in the incoming flow of payments in April-May 2020 to almost zero. In such conditions, tour operators, travel agents, hotels, carriers, and other tourist-market actors suffered serious losses.

The most difficult month for the industry was May 2020. According to Rosstat, the decrease in the volume of services provided to the population by travel agencies and tour operators was $98 \%$, while hotel services fell by $88 \%$. From April to August 2020, 60 companies providing travel services were excluded from the Rostourism Register of Tour Operators, partly due to the insurance firms' refusal to provide financial guarantees to tour operators. The demand for the services of Russian hotels in the most popular local destinations began to recover only in July-August. According to Cushman and Wakefield forecasts, the Russian tourism and hospitality market would begin to gradually recover only in the second half of 2020, and the full recovery of the industry will take three to five years.

Since March 2020, Sberbank has been publishing data on the dynamics of domestic tourism, namely weekly travel flows inside Russia. The Tourism Index reflects the change in the number of tourists in a selected region relative to the comparable week of 2019. In Figure 1, the value stands for the change over the respective week of 2019. Lower values imply greater loss of visitors to the region, but do not provide qualitative assessment. For example, extremely low values for the Krasnodar region during the pandemic mean that the number of travelers dropped significantly, but they do not convey information about the infrastructure, HoReCa (Hotel-Restaurant-Cafe/Catering/Casino) development, etc. The indicator does not track changes related to infrastructure or other qualitative factors-low indicators for a region during a pandemic indicate a loss of tourist flow, but do not imply underdevelopment of the industry.

Analysis of consumer-spending structure and dynamics in different categories shows that although the volume of consumer spending recovered to the level of 2019, the demand for certain items remained at a low level. These were the costs of purchasing air tickets, hospitality services, entertainment, and transportation. Thus, at the end of August, the cost of hotels was almost two times lower than the level in 2019, the cost of buying air tickets was $34.7 \%$ lower, and the cost of travel agency services was 10.8\% lower. In Figure 2, we can observe active retail outlets, normalized to the average weekly value for February 2020. Starting 28 July 2020, there was a significant adjustment to this section. We now track small and medium-sized businesses, and specifically retail outlets that have any $b 2 c$ transaction activity. Importantly, we now use the same sample as in the business-turnover tracker. 


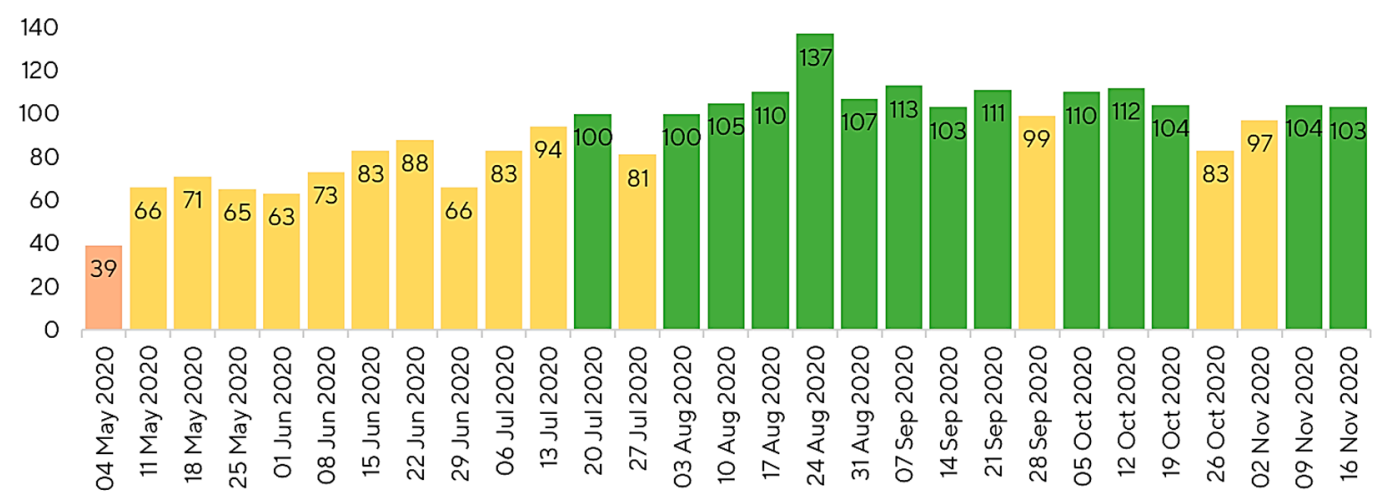

Figure 1. Tourism index, Russia (project \#Sberindex). Source: https://www.sberindex.ru/en/dashboards/indeksvnutrennego-turizma-pomesyachnaya-dinamika?partition=9\&tags $\% 5 \mathrm{~B} \% 5 \mathrm{D}=6$ (accessed on 30 January 2021).

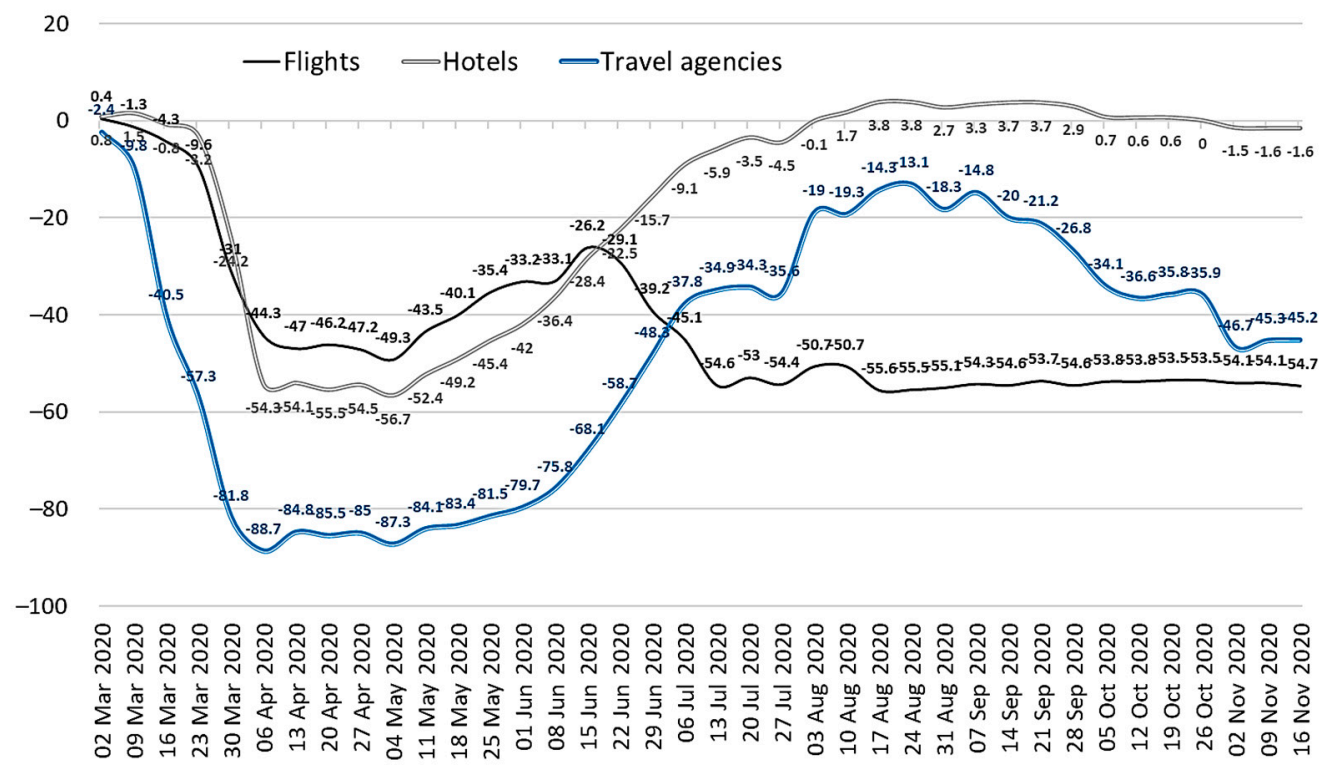

Figure 2. Change in consumer spending in \% compared to the same week in 2019 according to Sberbank (project\# Sberindex). Source: https:/ / sberindex.ru/en/dashboards/izmenenie-aktivnosti-msp?partition=2 (accessed on 30 January 2021).

Rosstat provides information on the volume of services provided by the hospitality industries (hotel services, collective accommodation facilities, travel agencies, and tour operators). The data come with a delay of about two months. Based on these data, one can judge a significant decrease in the output of services in tourism compared to the same period of the previous year (in May to almost zero), then a recovery in demand for services since June. Still, considering the COVID-19 pandemic is an ongoing crisis, the outlook remains highly uncertain (Figure 3).

The Bank of Russia publishes aggregate data on sectoral inbound and outbound flows, which makes it possible to assess the decline in the financial security of enterprises. We can see that the tourism sector continued to lead the ranking of industries with the largest lag in incoming flows. The deviation for the industry "activities of travel agencies" in the week of 10-14 August was $-63 \%$ from the "normal time" level. This means the average level of daily seasonally adjusted incoming payments for the period from January to March 2020. Since July, there was a recovery growth in incoming flows for "providing temporary accommodation", namely hotels, hostels, sanatoriums, recreation centers, etc., but one should keep in mind that the "normal time" for this type of activity is summertime, not January-March (Figure 4). 


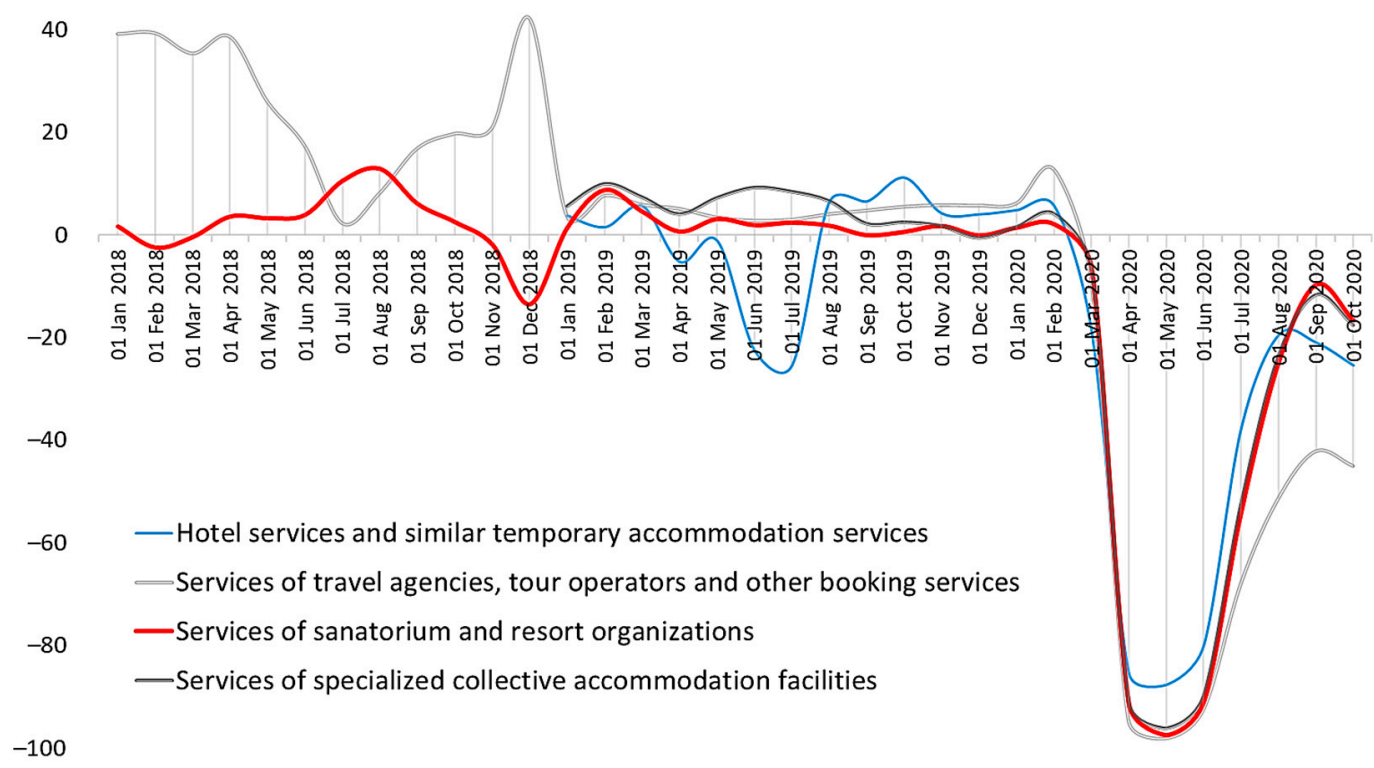

Figure 3. The growth rate of services provided by the hospitality industry, \% (compared to the same period in 2019) according to Rosstat. Source: https: / www.fedstat.ru/indicator/57788 (accessed on 30 January 2021).

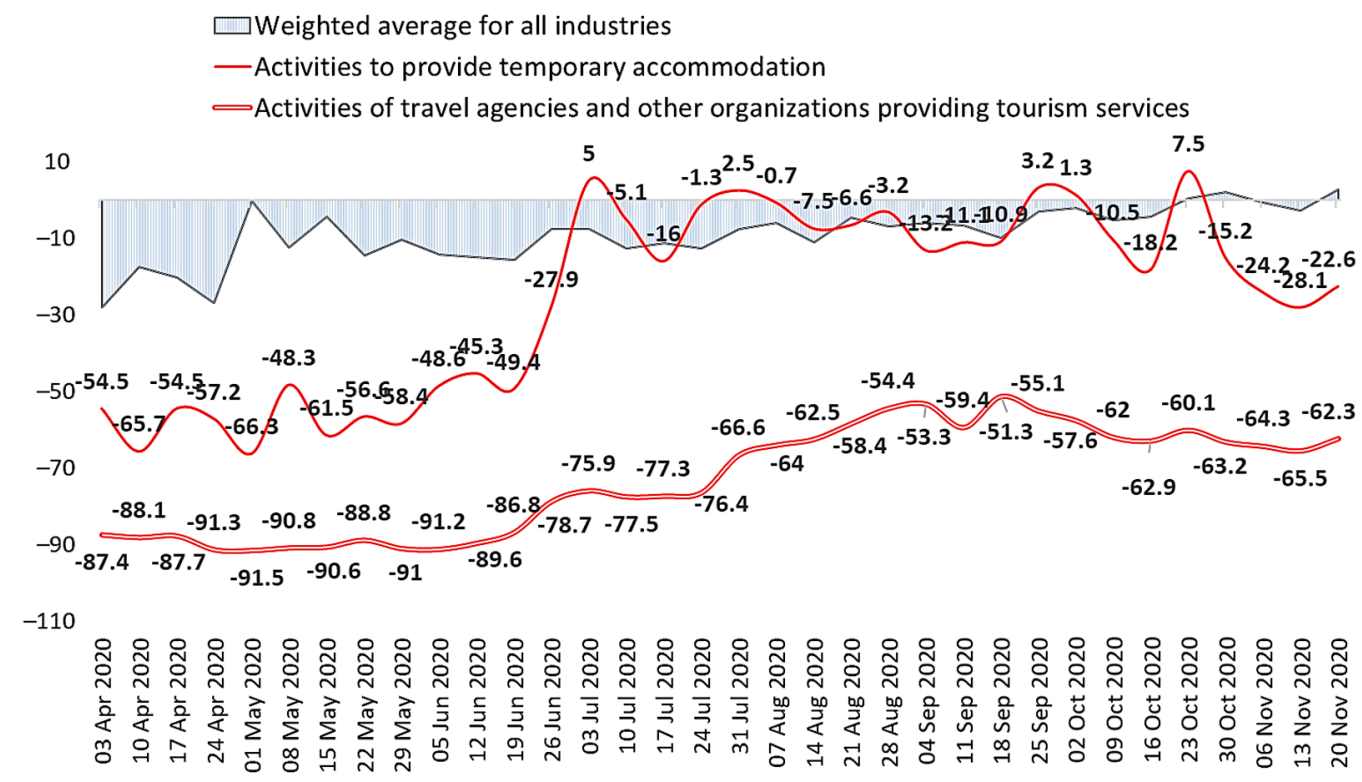

Figure 4. Change of money inflow by industry, \% change from "normal" level ("monitoring of financial flows" according to the Bank of Russia). Source: https:/ / cbr.ru/analytics/finflows/ (accessed on 30 January 2021).

\subsection{Tourism SMEs in the Nizhny Novgorod Region: Statistics and Survey Results}

An additional source of information can be the level of payments from profit or from turnover in the context of industries and regions. The data on the amount of income tax and VAT from hospitality enterprises in the Nizhny Novgorod region gave an operational picture of the financial condition and volume of services provided. For hotels, a slight recovery of activity was noticeable since August, but for travel agencies, the main activity remained unprofitable.

The Federal Tax Service has been maintaining the Unified Register of Small and Medium Enterprises since 2007. Entries into and exclusions from the register are carried out by the Federal Tax Service on the basis of information from the Unified State Register of 
Legal Entities; the Unified State Register of Individual Entrepreneurs; information on the average number of employees, income, and the use of special tax regimes; and information provided by stock exchanges, the Russian Ministry of Education and Science, the Skolkovo Foundation, the Russian Ministry of Economic Development, the Russian Ministry of Industry and Trade, holders of joint-stock companies' shareholder registers, and audit organizations.

Comparison of register data for different periods allows us to assess the current number of SME dynamics in the context of regions and sectors of the economy. Most of the hospitality sector firms belong specifically to the SME segment. So, in August 2020 in the Nizhny Novgorod region, 383 SMEs were registered under code 55 (activities for the provision of temporary residence), of which 342 were microenterprises, 38 were small enterprises, and three were medium-sized enterprises. Out of 849 Nizhny Novgorod SMEs under code 79 (activities of travel agencies and other organizations providing tourism services), 837 were microenterprises, and 12 were small-sized firms (Figure 5).

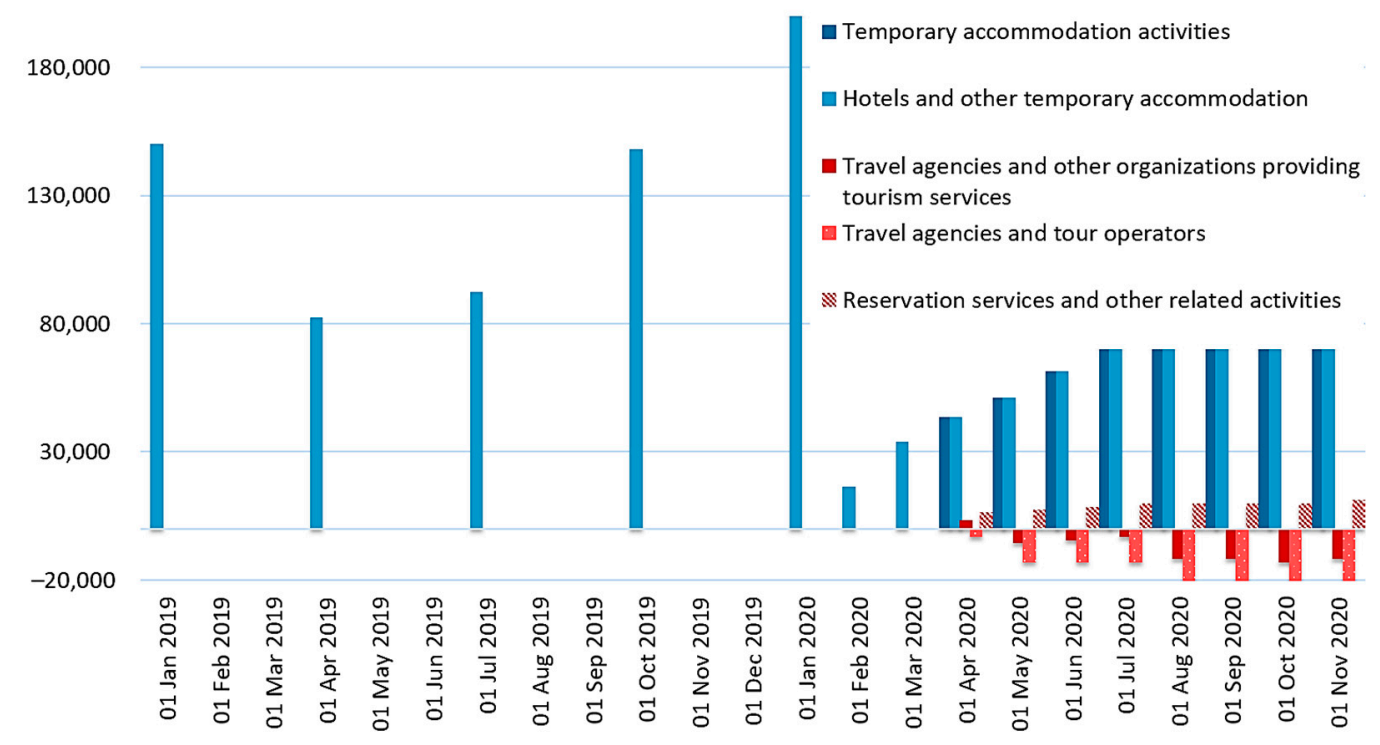

Figure 5. Income tax and VAT from enterprises of hospitality industry, Nizhny Novgorod region (Federal Tax Service data). Source: https://www.nalog.ru/rn52/related_activities/statistics_and_analytics/forms/9694695/ (accessed on 30 January 2021).

The data were collected by the authors in August 2020 (the period between the first and second outbreak of coronavirus) in the Nizhny Novgorod region. The choice of location for the survey was not accidental: the Nizhny Novgorod region is located $450 \mathrm{~km}$ from Moscow, its population is about 1.3 million people; it has average demographic, social, and economic indicators in Russia, and thus quite well represents the country as a whole. In addition, this is a typical region from the tourism-development point of view, with a large but not fully realized tourism potential. Therefore, the situation here largely describes the situation in the Russian tourism market.

The results of the study based on the example of the Nizhny Novgorod region contribute to obtaining a more objective picture for understanding the processes and mechanisms of local tourism SMEs' adaptation to global challenges. Based on the collected data, it is possible to get a general picture of how they are responding to the challenges caused by COVID-19, to summarize their anticrisis solutions of the respondent enterprises, and determine the place of marketing innovations in their tactics of doing business in an unprecedented crisis (Table 1). 
Table 1. Survey results.

\begin{tabular}{|c|c|c|c|}
\hline & Question & Answers & $\begin{array}{l}\text { Number and } \\
\text { Percentage of } \\
\text { Respondents }\end{array}$ \\
\hline \multirow{3}{*}{1} & \multirow{3}{*}{$\begin{array}{l}\text { The scale of business } \\
\text { decline }\end{array}$} & Insignificant & $3(5 \%)$ \\
\hline & & Significant & $38(60 \%)$ \\
\hline & & Critical & $22(35 \%)$ \\
\hline \multirow{5}{*}{2} & \multirow{5}{*}{ The drop in sales } & $<20 \%$ & - \\
\hline & & $21-40 \%$ & - \\
\hline & & $41-60 \%$ & $16(25 \%)$ \\
\hline & & $61-80 \%$ & $37(59 \%)$ \\
\hline & & $>80 \%$ & $10(16 \%)$ \\
\hline \multirow{3}{*}{3} & \multirow{3}{*}{$\begin{array}{l}\text { How many days would } \\
\text { your company be able to } \\
\text { live on funds in accounts } \\
\text { in the absence of money } \\
\text { inflows (if there are } \\
\text { constant costs)? }\end{array}$} & $<30$ & $25(40 \%)$ \\
\hline & & $30-60$ & $28(44 \%)$ \\
\hline & & 90-120 & $10(16 \%)$ \\
\hline \multirow{15}{*}{4} & \multirow{15}{*}{$\begin{array}{l}\text { What anticrisis measures } \\
\text { will you implement at } \\
\text { your enterprise? } \\
\text { (Multiple answer options } \\
\text { possible) }\end{array}$} & Changing business strategy/Vision & $28(44 \%)$ \\
\hline & & Replacement of key specialists & $2(3 \%)$ \\
\hline & & Business Process Reengineering & $9(14 \%)$ \\
\hline & & Staff reduction & $33(52 \%)$ \\
\hline & & Innovating & $9(14 \%)$ \\
\hline & & Lower wages & $16(25 \%)$ \\
\hline & & Reconstruction of the logistics base & $7(11 \%)$ \\
\hline & & $\begin{array}{l}\text { I will keep the staff, but I will take a } \\
\text { salary loan for employees }\end{array}$ & $16(25 \%)$ \\
\hline & & Increased use of digital technologies & $16(25 \%)$ \\
\hline & & Market withdrawal/Shutdown & $3(5 \%)$ \\
\hline & & Short-term shift to other services & $10(16 \%)$ \\
\hline & & Other & $7(11 \%)$ \\
\hline & & Reduced costs & $22(35 \%)$ \\
\hline & & Combining positions & $9(14 \%)$ \\
\hline & & Increasing customer orientation & $3(5 \%)$ \\
\hline \multirow{4}{*}{5} & \multirow{4}{*}{$\begin{array}{l}\text { Do you need financial } \\
\text { resources to grow your } \\
\text { business? }\end{array}$} & No, not required & $3(5 \%)$ \\
\hline & & Required, but we will cope on our own & $25(40 \%)$ \\
\hline & & Required, will have to take out a loan & $33(52 \%)$ \\
\hline & & Another & $2(3 \%)$ \\
\hline \multirow{6}{*}{6} & \multirow{6}{*}{$\begin{array}{l}\text { Have you used any state } \\
\text { support measures? }\end{array}$} & No, not used & $3(5 \%)$ \\
\hline & & Received a direct subsidy & $41(65 \%)$ \\
\hline & & Received a rental benefit & $9(14 \%)$ \\
\hline & & Received a tax benefit & $22(35 \%)$ \\
\hline & & Received an interest-free loan & $19(30 \%)$ \\
\hline & & Another & $3(5 \%)$ \\
\hline \multirow{3}{*}{7} & \multirow{3}{*}{$\begin{array}{l}\text { Has state support solved } \\
\text { any current problems? }\end{array}$} & Yes & $13(21 \%)$ \\
\hline & & $\begin{array}{l}\text { Partly, but state support was rather } \\
\text { insufficient/ineffective }\end{array}$ & $45(72 \%)$ \\
\hline & & $\begin{array}{l}\text { No, state support for us was not useful } \\
\text { in anything }\end{array}$ & $5(8 \%)$ \\
\hline \multirow{2}{*}{8} & \multirow{2}{*}{$\begin{array}{l}\text { Did your company } \\
\text { interrupt its busines } \\
\text { activity in a pandemic? }\end{array}$} & Yes & $47(75 \%)$ \\
\hline & & No & $16(25 \%)$ \\
\hline \multirow{4}{*}{9} & \multirow{4}{*}{$\begin{array}{c}\text { Has the staff of your } \\
\text { labor collective survived? }\end{array}$} & Yes & $25(40 \%)$ \\
\hline & & No, we had to reduce staff & $9(14 \%)$ \\
\hline & & No, some employees quit themselves & $25(40 \%)$ \\
\hline & & $\begin{array}{l}\text { No, there was a reduction in staff, and } \\
\text { the employees themselves were } \\
\text { leaving }\end{array}$ & $4(6 \%)$ \\
\hline
\end{tabular}


Table 1. Cont.

\begin{tabular}{|c|c|c|c|}
\hline & Question & Answers & $\begin{array}{l}\text { Number and } \\
\text { Percentage of } \\
\text { Respondents }\end{array}$ \\
\hline \multirow{5}{*}{10} & \multirow{5}{*}{$\begin{array}{l}\text { Did you have to cut } \\
\text { employee wages? }\end{array}$} & Yes & $27(43 \%)$ \\
\hline & & No & $13(21 \%)$ \\
\hline & & $\begin{array}{l}\text { Staff were formally reassigned to a } \\
\text { reduced schedule }\end{array}$ & $21(33 \%)$ \\
\hline & & $\begin{array}{l}\text { Employees were placed on unpaid } \\
\text { leave }\end{array}$ & $2(3 \%)$ \\
\hline & & Another & - \\
\hline \multirow{2}{*}{11} & \multirow{2}{*}{$\begin{array}{l}\text { Have you experienced } \\
\text { unfair behavior on the } \\
\text { part of your suppliers? }\end{array}$} & Yes & $41(65 \%)$ \\
\hline & & No & $22(35 \%)$ \\
\hline \multirow{3}{*}{12} & \multirow{3}{*}{$\begin{array}{l}\text { Have you encountered } \\
\text { legal problems (claims } \\
\text { and complaints) due to } \\
\text { the inability to fulfill } \\
\text { obligations to customers? }\end{array}$} & Yes & $28(44 \%)$ \\
\hline & & No & $35(56 \%)$ \\
\hline & & Another & - \\
\hline \multirow[t]{3}{*}{13} & $\begin{array}{l}\text { Have you managed to } \\
\text { solve these problems } \\
\text { without compromising } \\
\text { your }\end{array}$ & Yes & $47(75 \%)$ \\
\hline & business/negotiating & No & $7(11 \%)$ \\
\hline & with your customers? & Another & $9(14 \%)$ \\
\hline \multirow{4}{*}{14} & \multirow{4}{*}{$\begin{array}{l}\text { Have you repurposed } \\
\text { from offline to online } \\
\text { service? }\end{array}$} & $\begin{array}{l}\text { No, the specifics of our business does } \\
\text { not allow }\end{array}$ & $30(48 \%)$ \\
\hline & & $\begin{array}{l}\text { No, time constraints (and/or technical } \\
\text { resources) prevented rapid } \\
\text { repurposing }\end{array}$ & $2(3 \%)$ \\
\hline & & Yes, partially & $21(33 \%)$ \\
\hline & & $\begin{array}{l}\text { Yes, we are fully ready for online } \\
\text { format }\end{array}$ & $10(16 \%)$ \\
\hline \multirow{3}{*}{15} & \multirow{3}{*}{$\begin{array}{l}\text { Have you been able to } \\
\text { repurpose your business } \\
\text { to provide other services, } \\
\text { or service new } \\
\text { destinations? }\end{array}$} & Yes & $3(5 \%)$ \\
\hline & & No & $44(70 \%)$ \\
\hline & & Partially & $16(25 \%)$ \\
\hline \multirow{4}{*}{16} & \multirow{4}{*}{$\begin{array}{l}\text { Due to the pandemic, we } \\
\text { felt disappointed in our } \\
\text { work }\end{array}$} & Yes, absolutely agree & $6(10 \%)$ \\
\hline & & Yes rather than No & $3(5 \%)$ \\
\hline & & No rather than Yes & $21(33 \%)$ \\
\hline & & No, absolutely disagree & $33(52 \%)$ \\
\hline \multirow{4}{*}{17} & \multirow{4}{*}{$\begin{array}{l}\text { We sacrifice short-term } \\
\text { results and shareholder } \\
\text { value for the long-term } \\
\text { survival of our business }\end{array}$} & Yes, absolutely agree & $28(44 \%)$ \\
\hline & & Yes rather than No & $16(25 \%)$ \\
\hline & & No rather than Yes & $10(16 \%)$ \\
\hline & & No, absolutely disagree & $9(14 \%)$ \\
\hline \multirow{4}{*}{18} & \multirow{4}{*}{$\begin{array}{l}\text { In a pandemic, our team } \\
\text { has become more } \\
\text { cohesive }\end{array}$} & Yes, absolutely agree & $25(40 \%)$ \\
\hline & & Yes rather than No & $21(33 \%)$ \\
\hline & & No rather than Yes & $16(25 \%)$ \\
\hline & & No, absolutely disagree & $1(2 \%)$ \\
\hline \multirow{4}{*}{19} & \multirow{4}{*}{$\begin{array}{l}\text { The pandemic has } \\
\text { accelerated the } \\
\text { digitalization of our } \\
\text { business }\end{array}$} & Yes, absolutely agree & $47(75 \%)$ \\
\hline & & Yes rather than No & $13(21 \%)$ \\
\hline & & No rather than Yes & $3(5 \%)$ \\
\hline & & No, absolutely disagree & - \\
\hline
\end{tabular}


Table 1. Cont.

\begin{tabular}{|c|c|c|c|}
\hline & Question & Answers & $\begin{array}{l}\text { Number and } \\
\text { Percentage of } \\
\text { Respondents }\end{array}$ \\
\hline \multirow[t]{2}{*}{20} & \multirow[t]{2}{*}{$\begin{array}{l}\text { Did you provide social } \\
\text { assistance in a pandemic? }\end{array}$} & 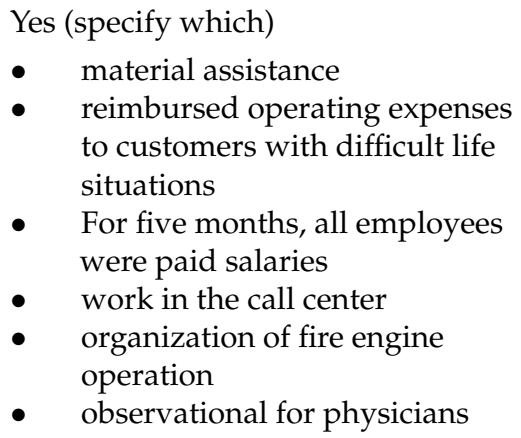 & $57(90 \%)$ \\
\hline & & No & $6(10 \%)$ \\
\hline 21 & $\begin{array}{c}\text { What factors hinder the } \\
\text { further development of } \\
\text { your business? }\end{array}$ & $\begin{array}{l}\text { Lack of finance } \\
\text { Lack of knowledge } \\
\text { Weak state support } \\
\text { Lack of qualified staff } \\
\text { Uncertainty related to COVID-19 } \\
\text { Other }\end{array}$ & $\begin{array}{l}35(56 \%) \\
- \\
28(44 \%) \\
13(21 \%) \\
57(90 \%) \\
10(16 \%)\end{array}$ \\
\hline
\end{tabular}

\section{Discussion}

Based on the data obtained, we can note the following.

The vast majority of the surveyed firms rated the scale of their business decline as significant and critical. Thus, the drop in sales for $60 \%$ of respondents was in the range of $40-60 \%$, and for $16 \%$ of respondents, the decrease in the volume of services provided was more than $80 \%$.

Most enterprises interrupted operations during the pandemic, but half of all firms retained their staff. Some travel agencies did without a reduction in wages, while $80 \%$ introduced a reduction in wages, a shorter work schedule, and a transfer to unpaid leave.

The surveyed firms considered a number of anticrisis measures, including a forced staff reduction (52\%) and a change in the strategy / concept of business development (44\%). A quarter of the surveyed firms thought of reducing wages; the same number of firms in the sample, on the contrary, were going to keep their staff but take a loan to pay salaries to employees. A third of the respondents were going to "improve customer focus", which implies both professional personnel skills development and a more broad range of services provided.

Only a quarter of respondents considered the wider use of digital technologies as an important tool to overcome the crisis. At the same time, only $50 \%$ of the surveyed travel agencies were able to switch, partially or completely, to online services; the specifics of their business and the lack of technical resources did not allow the rest to do this. Many firms were unable to convert their business to serve other areas, in spite of the fact that they had plans to change their business concept.

Among the state-support measures that tourism enterprises managed to take advantage of, they mentioned (in descending-frequency order) direct subsidies $(65 \%)$, tax incentives (35\%), loans (30\%), and rental incentives (14\%). For $21 \%$ of the respondents, state support was effective and solved some of the current problems (such as paying salaries, renting and maintaining offices, and paying bills), but most firms admitted that state support was insufficient and ineffective.

The in-depth interview results, on one hand, confirmed the unprecedentedness of the situation in which local tourism enterprises in Russia found themselves; on the other hand, they showed that they have proved to be quite resilient in extremely difficult conditions. 
Each owner of a hotel or travel agency tried to come up with an original solution for visitors to retain their constant audience. In conditions of (forced) localization and changing client behavior, it was necessary "to look for something new" - new offers for clients. Despite the fact that people could not go to public places with a large number of people, they could receive the necessary, interesting, and important information about the development and changes in this sector, and use part of the services at home. An example would be delivery from hotel restaurants. Travel agencies, realizing the difficult situation and the impossibility of selling a single tour, focused on maintaining and increasing their client bases for future tours.

The respondents pointed out some innovative trends that were evident before the pandemic and with a high likelihood to have a great impact on further tourism development in the postpandemic world. These were an increase in the number of amateur tourists and independent travel; increased demand for short-term rental housing; increased demand for road travel and road traffic; staycation and working practices; increasing demand for a new type of recreation-bleisure (business + leisure) or jleisure (job + leisure). Among the trends that became especially evident due to the pandemic's influence on consumer behavior were travel security and COVID-19 tourism, local agendas and short-term trips for short distances, solo travel, and increased interest in ecotourism.

Since tourism and hospitality services are most closely connected with human interactions that became partly or fully impossible in pandemic times, enterprises were interested in possible changes in their business models that could lean on digitalization and allow the replacement of human tourist guides with automatic services. For the staff of tourism enterprises, digital technology has become the only way to communicate with customers. In conditions of isolation and restrictions, our respondents underlined the importance of online contact with clients, both in terms of maintaining their customer base, and in terms of booking "future postpandemic trips" ("instead of kicking to a travel agency, potential clients do everything online"). Some respondents expressed an opinion that this will be a preferable (more cheap and secure) way of interaction with clients also in the postpandemic period.

Our respondents underlined the prospects of virtual tours that were growing in scope during the months of fighting the pandemic and were becoming a vital trend that will have a long-term impact on the market of sightseeing tours. So "making a virtual tour and showing people, for example, Thetyakov gallery pictures, can help to earn money and accommodate clients' demands" if properly incorporated into business models that take into account "digitalized" consumer choice through the use of applications such as Maps.me or Road.Travel. These apps allow users to build independent routes and share them with other users, and thus are in line with another important trend toward individualization and sharing of tourist-service consumption. Another app mentioned as prospective was izi.travel, which offers special audio guides for individual consumption while traveling on federal highways in Russia. One of the respondents pointed out that it makes sense for local tourism enterprises to take part in competitions supported by the Russian National map of local cultural brands (livingheritage.ru), which recently became a means to inform travelers about attractions in all Russian regions that are not broadly known.

One can state that despite the difficulties that hindered business development, among which were lack of funds, insufficient government support, and uncertainty associated with the epidemiological situation, most respondents did not feel disappointed in their business, and agreed with the statement that they "donate short-term results and shareholder value for the long-term survival of the business". Moreover, in the difficult conditions of the pandemic, the surveyed firms looked for additional opportunities and paid special attention to staff development, team consolidation, and marketing innovations. 


\section{Conclusions}

The global crisis of the COVID-19 pandemic, designated as a black swan event, has caused an unprecedented drop in the tourism business. Particularly vulnerable were small and medium-sized enterprises that did not have strong financial cushions and had to sacrifice operating profits for the sake of business survival.

Almost all foreign and Russian experts predict a continued crisis in the tourism and hospitality industry until 2023 or even 2024, and an increase in the cost of travel services in the long term. The crisis in the tourism sector in Russia led to the cessation of $30 \%$ of travel agencies, because tourism retail took the main hit. To maintain the functioning of this sphere, the government of the Russian Federation adopted a cashback program, subsidies for salaries to travel companies, and support by the state. However, these measures did not stop the fall of the industry. Of course, the field of tourism and hospitality will be revived, but the issues of when and which of the current market participants will be able to maintain position still remain.

Our survey showed that travel agencies had great adaptive opportunities for changing business strategies, one of which was the deep digitalization of the industry. The COVID-19 pandemic has accelerated the adoption of digital technologies in the tourism sector. The use of digital technologies in the context of the pandemic also performed a social function, allowing both employees and customers to not feel isolated from the outside world.

The in-depth interviews supported the opinion of many experts that indicated a number of innovative trends in the further development of tourism. Some of these trends were in place before the pandemic: an increase in the number of amateur tourists and independent organized travel, increased demand for short-term rental housing, increased demand for road travel and road traffic, staycation and working practices, and increasing demand for a new type of recreation-bleisure (business + leisure) or jleisure (job + leisure). Some trends can be called "pandemic-driven". These are travel security, prevailing interest in local travel and short-term trips for short distances, increased interest in ecotourism, and sharply decreased demand for traveling in large organized groups.

Russian enterprises in the pandemic crisis demonstrated a high level of social responsibility. Thus, most of the surveyed tourist enterprises have retained their teams. The crisis made employees more united, friendly, and responsible. The vast majority of employees, unable to fulfill their direct functional duties, agreed to perform difficult socially significant work, which is additional evidence of the high mobilization of personnel in crisis times. Government support measures helped to retain personnel and to pay salaries.

The obtained results can be important for government agencies, since the goals of the industry's sustainable development set in the working version of the National Project "Tourism" are impracticable without the provision of sustainable-development conditions healthy for numerous SMEs that form ecosystems of tourism destinations. Our results suggest adjustment of the implementation of state-support mechanisms. Therefore, there is a need to study more closely the problems faced by local tourism enterprises in obtaining state support during the COVID-19 pandemic, and to adjust the mechanisms for implementing state support.

The study presented in this paper has its limitations. All local-tourism enterprises that participated in the survey were from one region of the Russian Federation. Consequently, the results of the survey may have discrepancies compared to the study of the sample of tourism enterprises in the country as a whole. Another limitation is the short period of data collection between the first and second outbreak of COVID-19 in Russia. In the future, we plan to compare the survey conducted in August 2020 with the same survey conducted a year later, in order to understand which postpandemic recovery strategies will be undertaken by tourism enterprises.

Promising avenues of future research may be as follows. Currently, the devastating impact of the COVID-19 pandemic on tourism SVEs is clear, but the issue of long-term impact requires additional research. How will COVID-19 change the vision of sustainable tourism for small and medium-sized businesses? What are the opportunities and prospects 
for the development of the tourism economy in the long term? Will a short-term change in tourism-business technology lead to a long-term sustainable change, and if so, how? Will the pandemic result in moving the tourism business to online platforms? Is the need to work on the Internet transforming into a position of "living on the Internet", thereby creating a new threat? Given that the COVID-19 pandemic has spurred innovation, more research is needed to explore the priority areas for innovative development. Finally, it is necessary to get an exhaustive answer to questions regarding the negative and positive consequences that society and businesses will expect to realize from the pandemic in the future.

Author Contributions: Conceptualization, M.S.; methodology, M.S., L.V., and M.E.; validation, L.V. and A.P.; formal analysis, L.V. and M.E.; resources, L.V. and M.E.; data curation, L.V. and M.E.; writing-original draft preparation, M.S. and L.V.; writing-review and editing, M.S. and G.L.; supervision, M.S.; funding acquisition, M.S. and M.E. All authors have read and agreed to the published version of the manuscript.

Funding: This research was funded by the National Research Lobachevsky State University of Nizhny Novgorod under the research project "Sustainable development of small and medium-sized businesses in the face of big challenges", grant number H-443-99_2020-2021.

Informed Consent Statement: Informed consent was obtained from all subjects involved in the study.

Data Availability Statement: The data presented in this study are partly available on request from the corresponding author. Part of the data are not publicly available due to the conditions of the research carried out for a specific customer.

Conflicts of Interest: The authors declare no conflict of interest.

\section{References}

1. Hall, C.M.; Scott, D.; Gössling, S. Pandemics, transformations and tourism: Be careful what you wish for. Tour. Geogr. 2020, 22, 577-598. [CrossRef]

2. Bénassy-Quéré, A.; Marimon, R.; Pisani-Ferry, J.; Reichlin, L.; Schoenmaker, D.; Weder di Mauro, B. COVID-19: Europe Needs a Catastrophe Relief Plan. VOX CEPR Policy Portal. 11 March 2020. Available online: https:/ /voxeu.org/article/covid-19-europeneeds-catastrophe-relief-plan (accessed on 18 March 2021).

3. Lenzen, M.; Li, M.; Malik, A.; Pomponi, F.; Sun, Y.-Y.; Wiedmann, T.; Faturay, F.; Fry, J.; Gallego, B.; Geschke, A.; et al. Global socio-economic losses and environmental gains from the Coronavirus pandemic. PLoS ONE 2020, 15, e0235654. [CrossRef]

4. Gavurova, B.; Suhanyi, L.; Rigelský, M. Tourist spending and productivity of economy in OECD countries-Research on perspectives of sustainable tourism. Entrep. Sustain. Issues 2020, 8, 983-1000. [CrossRef]

5. Gössling, S.; Scott, D.; Hall, C.M. Pandemics, tourism and global change: A rapid assessment of COVID-19. J. Sustain. Tour. 2020, 29, 1-20. [CrossRef]

6. Tsionas, M.G. COVID-19 and gradual adjustment in the tourism, hospitality, and related industries. Tour. Econ. 2020, 15 . [CrossRef]

7. Haywood, K.M. A post COVID-19 future-Tourism re-imagined and re-enabled. Tour. Geogr. 2020, 22, 599-609. [CrossRef]

8. Higgins-Desbiolles, F. Socialising tourism for social and ecological justice after COVID-19. Tour. Geogr. 2020, 22, 610-623. [CrossRef]

9. Amankwah-Amoah, J.; Khan, Z.; Wood, G. COVID-19 and business failures: The paradoxes of experience, scale, and scope for theory and practice. Eur. Manag. J. 2020. [CrossRef]

10. Besenyő, J.; Kármán, M. Effects of COVID-19 pandemy on African health, political and economic strategy. Insights Reg. Dev. 2020, 2, 630-644. [CrossRef]

11. Donthu, N.; Gustafsson, A. Effects of COVID-19 on business and research. J. Bus. Res. 2020, 117, 284-289. [CrossRef]

12. Fetzer, T.; Witte, M.; Hensel, L.; Jachimowicz, J.M.; Haushofer, J.; Ivchenko, A.; Caria, S.A.; Reutskaja, E.; Roth, C.; Fiorin, S.; et al. Global Behaviours and Perceptions at the Onset of the COVID-19 Pandemic. Natl. Bur. Econ. Res. 2020. [CrossRef]

13. Jordà, Ò.; Singh, S.R.; Taylor, A.M. Longer-Run Economic Consequences of Pandemics; Federal Reserve Bank of San Francisco Working Paper No. 26934; National Bureau of Economic Research: Cambridge, MA, USA, 2020. [CrossRef]

14. Craven, M.; Liu, L.; Mysore, M.; Wilson, M. COVID-19: Implications for Business. Available online: https:/ /www.mckinsey.com/ business-functions/risk/our-insights / covid-19-implications-for-business\# (accessed on 9 December 2020).

15. Pantano, E.; Pizzi, G.; Scarpi, D.; Dennis, C. Competing during a pandemic? Retailers' ups and downs during the COVID-19 outbreak. J. Bus. Res. 2020, 116, 209-213. [CrossRef]

16. Krishnamurthy, S. The future of business education: A commentary in the shadow of the Covid-19 pandemic. J. Bus. Res. 2020, 117, 1-5. [CrossRef] 
17. Tucker, H. Coronavirus Bankruptcy Tracker: These Major Companies are Failing Amid the Shutdown. Forbes. 2020. Available online: https: / / www.forbes.com/sites/hanktucker/2020/05/03/coronavirus-bankruptcy-tracker-these-major-companies-arefailing-amid-theshutdown/\#5649f95d3425 (accessed on 16 December 2020).

18. Crick, J.M.; Crick, D. Coopetition and COVID-19: Collaborative business-to-business marketing strategies in a pandemic crisis. Ind. Mark. Manag. 2020, 88, 206-213. [CrossRef]

19. He, H.; Harris, L. The impact of Covid-19 pandemic on corporate social responsibility and marketing philosophy. J. Bus. Res. 2020, 116, 176-182. [CrossRef]

20. Bartik, A.W.; Bertrand, M.; Cullen, Z.; Glaeser, E.L.; Luca, M.; Stanton, C. The impact of COVID-19 on small business outcomes and expectations. Proc. Natl. Acad. Sci. USA 2020, 117, 17656-17666. [CrossRef] [PubMed]

21. Fairlie, R. The Impact of Covid-19 on Small Business Owners: Evidence of Early-Stage Losses from the April 2020 Current Population Survey; National Bureau of Economic Research: Cambridge, MA, USA, 2020.

22. Ferrando, A. Firms' Expectations on Access to Finance at the Early Stages of the Covid-19 Pandemic; ECB Working Paper No. 20202446, July 2020; European Central Bank: Frankfurt, Germany, 2020; Available online: https:/ /ssrn.com/abstract=3656265 (accessed on 23 March 2021).

23. Juergensen, J.; Guimón, J.; Narula, R. European SMEs amidst the COVID-19 crisis: Assessing impact and policy responses. J. Ind. Bus. Econ. 2020, 47, 499-510. [CrossRef]

24. Shafi, M.; Liu, J.; Ren, W. Impact of COVID-19 pandemic on micro, small, and medium-sized Enterprises operating in Pakistan. Res. Glob. 2020, 2, 100018. [CrossRef]

25. Syriopoulos, K. The impact of Covid-19 on entrepreneurship and SMES. J. Int. Acad. Case Stud. 2020, 26, 1-2. Available online: https:/ / search.proquest.com/docview/2419452454?accountid=35424 (accessed on 23 January 2021).

26. Lu, Y.; Wu, J.; Peng, J.; Lu, L. The perceived impact of the Covid-19 epidemic: Evidence from a sample of 4807 SMEs in Sichuan Province, China. Environ. Hazards 2020, 19, 323-340. [CrossRef]

27. Eggers, F. Masters of disasters? Challenges and opportunities for SMEs in times of crisis. J. Bus. Res. 2020, 116, 199-208. [CrossRef]

28. Alonso, A.D.; Kok, S.K.; Bressan, A.; O'Shea, M.; Sakellarios, N.; Koresis, A.; Solis, M.A.B.; Santoni, L.J. COVID-19, aftermath, impacts, and hospitality firms: An international perspective. Int. J. Hosp. Manag. 2020, 91, 102654. [CrossRef]

29. Kuckertz, A.; Brändle, L.; Gaudig, A.; Hinderer, S.; Reyes, C.A.M.; Prochotta, A.; Steinbrink, K.M.; Berger, E.S. Startups in times of crisis-A rapid response to the COVID-19 pandemic. J. Bus. Ventur. Insights 2020, 13, e00169. [CrossRef]

30. Thorgren, S.; Williams, T.A. Staying alive during an unfolding crisis: How SMEs ward off impending disaster. J. Bus. Ventur. Insights 2020, 14, e00187. [CrossRef]

31. Jnr, B.A.; Petersen, S.A. Examining the digitalisation of virtual enterprises amidst the COVID-19 pandemic: A systematic and meta-analysis. Enterp. Inf. Syst. 2020, 1-34. [CrossRef]

32. Efremova, M.V.; Sheresheva, M.Y.; Valitova, L.A. Post-Pandemic challenges and prospects for SMEs in the Russian tourism sector. In Proceedings of the 33rd EBES Conference, Madrid, Spain, 7-9 October 2020.

33. Priyono, A.; Moin, A.; Putri, V.N.A.O. Identifying Digital Transformation Paths in the Business Model of SMEs during the COVID-19 Pandemic. J. Open Innov. Technol. Mark. Complex. 2020, 6, 104. [CrossRef]

34. Benn, S.; Edwards, M.; Williams, T. Organizational Change for Corporate Sustainability; Routledge \& CRC Press: Oxfordshire, UK, 2018.

35. Ritter, T.; Pedersen, C.L. Analyzing the impact of the coronavirus crisis on business models. Ind. Mark. Manag. 2020, 88, 214-224. [CrossRef]

36. Belso-Martínez, J.A.; Mas-Tur, A.; Sánchez, M.; López-Sánchez, M.J. The COVID-19 response system and collective social service provision. Strategic network dimensions and proximity considerations. Serv. Bus. 2020, 14, 387-411. [CrossRef]

37. Baum, T.; Hai, N.T.T. Hospitality, tourism, human rights and the impact of COVID-19. Int. J. Contemp. Hosp. Manag. 2020, 32, 2397-2407. [CrossRef]

38. Sheresheva, M.Y. Coronavirus and tourism. Popul. Econ. 2020, 4, 72-76. [CrossRef]

39. Brouder, P. Reset redux: Possible evolutionary pathways towards the transformation of tourism in a COVID-19 world. Tour. Geogr. 2020, 22, 484-490. [CrossRef]

40. Niewiadomski, P. COVID-19: From temporary de-globalisation to a re-discovery of tourism? Tour. Geogr. 2020, 22, 651-656. [CrossRef]

41. Romagosa, F. The COVID-19 crisis: Opportunities for sustainable and proximity tourism. Tour. Geogr. 2020, 22, 690-694. [CrossRef]

42. Assaf, A.; Scuderi, R. COVID-19 and the recovery of the tourism industry. Tour. Econ. 2020, 26, 731-733. [CrossRef]

43. Zeng, Z.; Chen, P.-J.; Lew, A.A. From high-touch to high-tech: COVID-19 drives robotics adoption. Tour. Geogr. 2020, 22, 724-734. [CrossRef]

44. Żemła, M. Tourism destination: The networking approach. Morav. Geogr. Rep. 2016, 24, 2-14. [CrossRef]

45. Perkins, R.; Khoo-Lattimore, C.; Arcodia, C. Understanding the contribution of stakeholder collaboration towards regional destination branding: A systematic narrative literature review. J. Hosp. Tour. Manag. 2020, 43, 250-258. [CrossRef]

46. Dhewanto, W.; Nazmuzzaman, E.; Fauzan, T.R. Cross-countries' policies comparison of supporting small and medium-sized enterprises during Covid-19 pandemic. In Proceedings of the ECIE 2020 16th European Conference on Innovation and Entrepreneurship Academic Conferences Limited, Lisbon, Portugal, 17-18 September 2020; p. 218. 
47. Javed, A. Impact of COVID-19 on Pakistan's services sector. J. Inov. Èkon. 2020, 5, 107-116. [CrossRef]

48. Merkel, L.; Feißt, R.; Müller, P. Spanish Government Measures for SME Exporters in Times of COVID-19 Crisis; IfTI Working Paper December 2020; Hochschule Offenburg: Offenburg, Germany, 2020; Available online: https:/ / opus.hs-offenburg.de/frontdoor/ deliver/index/docId/4135/file/Essay_Spain_final.pdf (accessed on 9 February 2021).

49. World Tourism Organization. Supporting Jobs and Economies through Travel \& Tourism-A Call for Action to Mitigate the Socio-Economic Impact of COVID-19 and Accelerate Recovery; The World Tourism Organization (UNWTO): Madrid, Spain, 2020. [CrossRef]

50. Kock, F.; Nørfelt, A.; Josiassen, A.; Assaf, A.G.; Tsionas, M.G. Understanding the COVID-19 tourist psyche: The evolutionary tourism paradigm. Ann. Tour. Res. 2020, 85, 103053. [CrossRef] [PubMed]

51. Laato, S.; Islam, A.N.; Farooq, A.; Dhir, A. Unusual purchasing behavior during the early stages of the COVID-19 pandemic: The stimulus-organism-response approach. J. Retail. Consum. Serv. 2020, 57, 102224. [CrossRef]

52. Sheth, J. Impact of Covid-19 on consumer behavior: Will the old habits return or die? J. Bus. Res. 2020, 117, 280-283. [CrossRef]

53. Gursoy, D.; Chi, C.G. Effects of COVID-19 pandemic on hospitality industry: Review of the current situations and a research agenda. J. Hosp. Mark. Manag. 2020, 29, 527-529. [CrossRef]

54. Kourgiantakis, M.; Apostolakis, A.; Dimou, I. COVID-19 and holiday intentions: The case of Crete, Greece. Anatolia 2021, 32, 148-151. [CrossRef]

55. Han, H.; Al-Ansi, A.; Chua, B.-L.; Tariq, B.; Radic, A.; Park, S.-H. The Post-Coronavirus World in the International Tourism Industry: Application of the Theory of Planned Behavior to Safer Destination Choices in the Case of US Outbound Tourism. Int. J. Environ. Res. Public Health 2020, 17, 6485. [CrossRef]

56. Zenker, S.; Kock, F. The coronavirus pandemic-A critical discussion of a tourism research agenda. Tour. Manag. 2020, 81, 104164. [CrossRef]

57. Hao, F.; Xiao, Q.; Chon, K. COVID-19 and China's Hotel Industry: Impacts, a Disaster Management Framework, and PostPandemic Agenda. Int. J. Hosp. Manag. 2020, 90, 102636. [CrossRef]

58. Radovič-Markovič, M.; Živanovič, B. Fostering green entrepreneurship and women's empowerment through education and banks' investments in tourism: Evidence from Serbia. Sustainability 2019, 11, 6826. [CrossRef]

59. Mirskikh, I.; Mingaleva, Z.; Kuranov, V.; Matseeva, S. Digitization of Medicine in Russia: Mainstream Development and Potential. Lect. Notes Netw. Syst. 2021, 136, 337-345. [CrossRef]

60. Wen, J.; Wang, W.; Kozak, M.; Liu, X.; Hou, H. Many brains are better than one: The importance of interdisciplinary studies on COVID-19 in and beyond tourism. Tour. Recreat. Res. 2020, 1-4. [CrossRef]

61. Polemis, M.; Stengos, T. Threshold Effects during the COVID-19 Pandemic: Evidence from International Tourist Destinations. Munich Personal RePEc Archive; MPRA Paper No. 102845; University of Piraeus, Guelph University: Guelph, ON, Canada, 2020; Available online: https:/ / mpra.ub.uni-muenchen.de/102845/1/MPRA_paper_102845.pdf (accessed on 19 January 2021).

62. Chang, C.-L.; McAleer, M.; Ramos, V. A Charter for Sustainable Tourism after COVID-19. Sustainability 2020, 12, 3671. [CrossRef]

63. Mingaleva, Z. On digital development of Russian urban transport infrastructure. Adv. Intell. Syst. Comput. 2019, 850, 29-35. [CrossRef]

64. Reyes-Menendez, A.; Correia, M.; Matos, N.; Adap, C. Understanding Online Consumer Behavior and eWOM Strategies for Sustainable Business Management in the Tourism Industry. Sustainability 2020, 12, 8972. [CrossRef]

65. Saura, J.R.; Reyes-Menendez, A.; Palos-Sanchez, P.R. The digital tourism business: A systematic review of essential digital marketing strategies and trends. In Digital Marketing Strategies for Tourism, Hospitality, and Airline Industries; IGI Global: Hershey, PA, USA, 2020; pp. 1-22.

66. Alves, G.M.; Sousa, B.M.; Machado, A. The role of digital marketing and online relationship quality in social tourism: A tourism for all case study. In Digital Marketing Strategies for Tourism, Hospitality, and Airline Industries; IGI Global: Hershey, PA, USA, 2020; pp. $49-90$.

67. Legard, R.; Keegan, J.; Ward, K. In-depth Interviews. Qualitative Research Practice: A guide for Social Science Students and Researchers; SAGE Publications: London, UK, 2003; Volume 6, pp. 138-169.

68. Sheresheva, M.; Valitova, L.; Tsenzharik, M.; Oborin, M. Industrial Life-Cycle and the Development of the Russian Tourism Industry. J. Risk Financ. Manag. 2020, 13, 113. [CrossRef]

69. Andrades, L.; Dimanche, F. Destination competitiveness and tourism development in Russia: Issues and challenges. Tour. Manag. 2017, 62, 360-376. [CrossRef]

70. Andrades, L.; Dimanche, F. Destination competitiveness in Russia: Tourism professionals' skills and competences. Int. J. Contemp. Hosp. Manag. 2019, 31, 910-930. [CrossRef]

71. Chkalova, O.; Efremova, M.; Lezhnin, V.; Polukhina, A.; Sheresheva, M. Innovative mechanism for local tourism system management: A case study. Entrep. Sustain. Issues 2019, 6, 2052-2067. [CrossRef]

72. Polukhina, A.N.; Sheresheva, M.Y.; Rukomoinikova, V.P.; Napol'skikh, D.L. The rationale for comparative effec-tiveness of tourist potential realization (case study of the Volga Region). Econ. Soc. Chang. Facts Trends Forecast 2016, 5, 122-140. [CrossRef]

73. Polukhina, A.; Sheresheva, M.; Efremova, M.; Suranova, O.; Agalakova, O.; Antonov-Ovseenko, A. The Concept of Sustainable Rural Tourism Development in the Face of COVID-19 Crisis: Evidence from Russia. J. Risk Financ. Manag. 2021, 14, 38. [CrossRef] 